\title{
Value Chain of Poultry Hatcheries in BANGLADESH: A COMPARATIVE STUDY OF SMES Versus Large Players by Porter's VAlue Chain Model
}

\author{
Md. Shamsuzzaman ${ }^{1}$ and Sheikh Morshed Jahan ${ }^{2}$ \\ ${ }^{1}$ DBA Research Fellow, Institute of Business Administration, University of Dhaka, \\ Bangladesh. \\ ${ }^{2}$ Associate Professor, Institute of Business Administration, University of Dhaka, \\ Bangladesh.
}

\begin{abstract}
:
The contribution of animal farming subsector to GDP of Bangladesh at constant price is 1.66 percent, of which more than fifty percent is contributed by poultry industry. Poultry hatchery is the backbone of this industry. This research has tried to explore the value chain dynamics and challenges of integration faced by SMEs vis-à-vis larger poultry hatcheries. The research framework is designed along Porter's value chain model. Primary data were collected from 20 chief executives and senior management professionals from hatcheries of varied sizes that supply more than $60 \%$ of the demand for chicks.The research has found that larger hatcheriesenjoy significant competitive advantage over their SME counterparts due to extensive value chain presence, use of modern technologies, methods and processes, stronger brand image, proper marketing activities, effective customer services, better economies of scale and scope, continuous technological development, proper people management and stronger infrastructural support.
\end{abstract}

\section{KEYWORDS :}

Poultry Hatchery, GP (Grand Parents), PS (Parents Stock), DOC (Day Old Chicken) \& SME (Small \& Medium Enterprise)

\section{INTRODUCTION}

When it comes to consumption of poultry meat, Bangladesh ranks as one of the lowest consuming countries. Industry observers claim that the average consumer eats about $3.2 \mathrm{kgs}$ of poultry meat annually. OEFD-FAO Agricultural Outlook (2016), however, states that the per capita consumption is even lower at just $1.2 \mathrm{kgs}$ per year per person.[]this figure is much lower than regional countries like India and Pakistan. High population density with larger poor and lower middle class segment resulting low purchase power parity is the prime causeof such kind of per capita consumption. That's why vast a segment of people consume meat occasionally and have a lower per capita income compared to the neighbors India and Pakistan, which need to be increased quickly to build a healthy nation. In comparison, Malaysia and the United States are at the top end of the poultry meat consumption chart, with $41.4 \mathrm{~kg}$ per capita and $47.6 \mathrm{~kg}$ per capita respectively [2\&3].

So it can be clearly concluded that there is a big gap between demand and supply of poultry meet in Bangladesh considering developed as well as developing neighboring countries. Now a day's poultry industry is one of the extreme potential sector for a developing country like Bangladesh, where poultry hatchery is the key. This industry has high potential to help nation by broadening the scope of food security especially enhancing protein availability, affordability and 
consumption, increasing purchase power by generating employment, minimizing balance of trade by using the export potentials, finally improving inclusive economic growth.

So we can say that one of the key strategy to alleviate some important national economic indicators of the country need to emphasize on the development of poultry industry strategically. On the contrary, development of poultry industry is highly dependent on proper value chain integration starting from poultry hatcheries. As a result, research work has high focused on analyzing all the most important components of hatchery's value chain and its challenges of integration SMEs versus large players.

Value chain analysis is very significant for the whole industry, particularly more useful for new venture - including SME players of developing countries - to enter into global markets in a manner which would provide for sustainable income growth.

According to Kaplinsky, R. and Morris, M. (2001) value chain analysis is also useful as an analytical tool in understanding the policy formulation which will ensure the efficient allocation of resources within the domestic economy, notwithstanding its primary use thus far as an analytic tool for understanding the way in which firms and countries participate in the global economy. Additionally they noticed that proper value chain integration during the era of rapid globalization has got high priority for the following three reason -

$>$ With ever growing division of labor and the global scattering of production of various components, systematic competitiveness has become increasingly important.

$>$ A necessary condition for successfully penetrating global markets is efficiency.

$>$ Entry into global markets allow for sustained income growth. This means that, making the best out of globalization requires the understanding of all the dynamic factors within the whole value chain.[4]

\section{OBJECTIVES OF THE RESEARCH}

\subsection{Broad Objective:}

To analyze the challenges of value chain integration of poultry hatcheries in Bangladesh on the basis of Porter's basic value chain model, giving special emphasis on SMEs versus large hatcheries which will help to identify competitive dynamics of poultry hatcheries.

\subsection{Specific Objective:}

- To explore the challenges of SME vs. large hatcheries for value chain integration considering generic categories of primary activities of Porter's value chain model such as inbound logistics, operation, outbound logistics, marketing and sales, and services.

- To analyze the challenges of SME vs. large hatcheries for value chain integration considering generic categories of support activities of Porter's value chain model such as procurement, technology development, human resource management, and infrastructure development.

- To determine how poultry hatcheries across the firm size can help each other in case value chain integration which can play vital role in the inclusive growth of the industry.

\section{Literature Review}

In the year 1985 Michael E. Porter has defined as well as elaborately described the term 'ValueChain'inhisbook"CompetitiveAdvantage: Creating and SustainingsuperiorPerformance"He has defined value chain as the whole series of activities that create and build value at every step. The total value delivered by the company is the sum total of the value built up all throughout the 
company.

According to Kaplinsky, R. and Morris, M. (2001), the value chain describes the full range of activities which are required to bring a product or service from conception, through the different phases of production (involving a combination of physical transformation and the input of various producer services), delivery to final consumers, and final disposal after use [4].

As per the definition of World Business Council for Sustainable Development (WBCSD, 2011) "Value chains are an integral part of strategic planning for many businesses today. A value chain refers to the full life cycle of a product or process, including material sourcing, production, consumption and disposal/recycling processes." [5]

According to The Global Value Chains Initiative "The value chain describes the full range of activities that firms and workers do to bring a product from its conception to its end use and beyond. This includes activities such as design, production, marketing, distribution and support to the final consumer. The activities that comprise a value chain can be contained within a single firm or divided among different firms. Value chain activities can produce goods or services, and can be contained within a single geographical location or spread over wider areas."[7]

Value Chain proposition, theorized by Porter, E.M. in 1985, is one of the proven most popular and effective as well as efficient business tool for business professionals such as entrepreneurs, marketers, and researchers for creating sustainable competitive advantage. However, key challenges for implementation of the Value Chain concept involves integration and value adding at each and every stage of the chain. Since, Value chain analysis describes the activities within and around an organization, and relates them to an analysis of the competitive strength of the organization. Therefore, it evaluates which value each particular activity adds to the organizations products or services.[6]

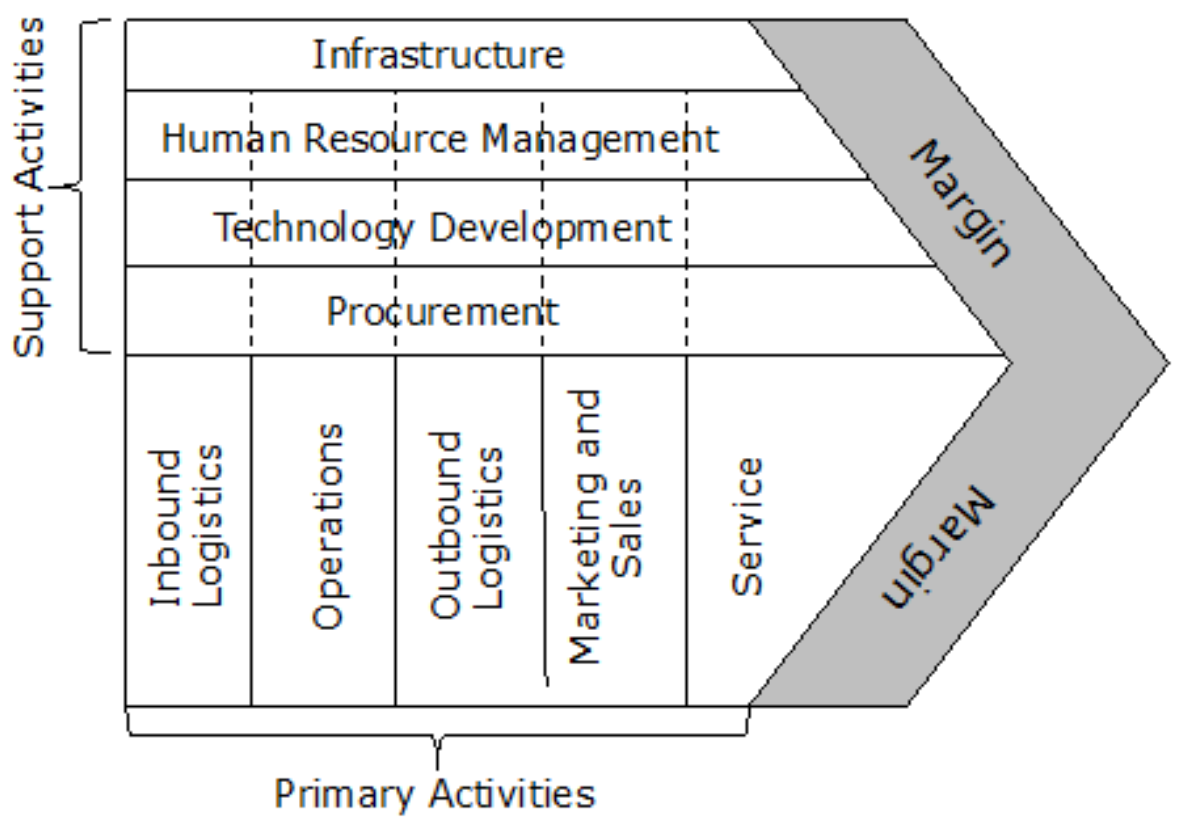

Figure : Basic value chain model (Can be considered as poultry hatchery value chain) Source: Michael Porter (1985) 
As per the above basic value chain model Michael E. Porter defines the value chain as made of primary activities and support activities. Primary involves inbound logistics, operations, outbound logistics, marketing and sales and service. The support functions which feed into all the primary functions are the firm infrastructure, Human Resource, technology and procurement. Both these allow the firm to charge a margin, which partly comes from the value addition of the primary and support functions and partly from the advantage that the company gains due to communication of the value addition to the consumer (brand image, faith, trust and so on) [6]

Considering the definition of Michael E. Porter's value chain it is revealed in the research that differences between SMEs and Large poultry hatchery's value chainis the key source of competitive advantage. Since, he has expressed that a farm's value chain in an industry may vary somewhat for different item in its product line, or different buyers, geographic location, or distribution channels, even it is the key source of competitive advantage. He also explained that the value chain for such subsets of a firm are closely related, however, and can only be understood in the context of the business unit chain. He also defined value as the amount buyers are willing to pay for what a firm provides them. It is measured by total revenue, a reflection of the firm's product commands and the unit it can sell. A firm is profitable if the value it commands exceeds the costs involved in creating the product. Creating value for buyers that exceeds the cost of doing so is the goal of any generic strategy. Value, instead of cost, must be used in analyzing competitive position since firm often deliberately raise their cost in order to command a premium price via differentiation. [6]

On the basis of above research model a detail chart has been developed on which comparative study on challenges of value chain integration between SME and large hatcheries will be explored by the researchers.

Chart no - 1A (Research schema)

\begin{tabular}{|c|c|c|c|}
\hline $\begin{array}{l}\text { Value } \\
\text { activities } \\
\text { (Parameter) }\end{array}$ & $\begin{array}{l}\text { Generic } \\
\text { categories } \\
\text { (Complex } \\
\text { Variable) }\end{array}$ & $\begin{array}{l}\text { Definition of Porter's activities } \\
\text { on poultry hatchery (Definition } \\
\text { of complex variables) }\end{array}$ & $\begin{array}{l}\text { Major activities in relation } \\
\text { to poultry hatchery } \\
\text { (Simple Variables) }\end{array}$ \\
\hline \multirow{2}{*}{$\begin{array}{l}\text { Primary } \\
\text { activities }\end{array}$} & $\begin{array}{l}\text { Inbound } \\
\text { logistics }\end{array}$ & $\begin{array}{l}\text { Initial phase of distribution } \\
\text { channel which starts with } \\
\text { receiving basic input such as } \\
\text { DOC, poultry feed material etc. } \\
\text { and its proper transportation to } \\
\text { the place of operation e.g. } \\
\text { hatchery for final output- } \\
\text { commercial DOC. }\end{array}$ & $\begin{array}{l}\text { Receiving, handling, } \\
\text { warehousing, transporting } \\
\text { and managing inventory of } \\
\text { hatchery inputs such as GP- } \\
\text { DOC, PS-DOC and basic } \\
\text { raw materials for poultry } \\
\text { feed material( Since all } \\
\text { most all hatcheries have } \\
\text { feed mill) }\end{array}$ \\
\hline & Operations & $\begin{array}{l}\text { Effective and efficient use of } \\
\text { man, machine and method for } \\
\text { transforming input means fertile } \\
\text { egg into final output - } \\
\text { commercial DOC, including } \\
\text { rearing of parent's layer and } \\
\text { practicing the best bio-security } \\
\text { and waste management process. }\end{array}$ & $\begin{array}{l}\text { Rearing, feeding, breeding, } \\
\text { egg collecting, grading, } \\
\text { setting, hatching, } \\
\text { maximizing production } \\
\text { efficiency. } \\
\text { Running and maintaining of } \\
\text { equipment, cleaning, } \\
\text { ensuring bio-security, safety } \\
\text { and waste management. }\end{array}$ \\
\hline
\end{tabular}




\begin{tabular}{|c|c|c|}
\hline $\begin{array}{l}\text { Outbound } \\
\text { Logistics }\end{array}$ & $\begin{array}{l}\text { The final phase of distribution } \\
\text { channel that starts with receiving } \\
\text { of commercial DOC, and } \\
\text { ensuring proper transportation to } \\
\text { the intermediaries or final buyer } \\
\text { following global standard. }\end{array}$ & $\begin{array}{l}\text { DOC collecting, handling, } \\
\text { warehousing, grading, } \\
\text { packing, printing, order } \\
\text { processing, scheduling, } \\
\text { loading, transporting, } \\
\text { unloading and training the } \\
\text { intermediaries for proper } \\
\text { secondary distribution of } \\
\text { DOC. }\end{array}$ \\
\hline $\begin{array}{l}\text { Marketing } \\
\text { and } \\
\text { Sales }\end{array}$ & $\begin{array}{l}\text { To create sustainable competitive } \\
\text { advantages in poultry hatchery's } \\
\text { business by adding superior } \\
\text { value in the brand at affordable } \\
\text { price through integrated } \\
\text { marketing communication. }\end{array}$ & $\begin{array}{l}\text { Value creation, pricing, } \\
\text { advertisement, sales } \\
\text { promotion, personal selling. } \\
\text { Intermediaries' } \\
\text { management. }\end{array}$ \\
\hline Service & $\begin{array}{l}\text { A set of activities starting from } \\
\text { idea selling to commercial DOC } \\
\text { selling by ensuring techno- } \\
\text { commercial support to enhance } \\
\& \text { maintain the desire value of } \\
\text { clients' end products such as live } \\
\text { bird, meat, egg etc. }\end{array}$ & $\begin{array}{l}\text { Idea selling to the } \\
\text { prospective customer, } \\
\text { ensuring technical support } \\
\text { to existing or potential } \\
\text { customers initiating with } \\
\text { infrastructure development, } \\
\text { brooding, breeding, feeding, } \\
\text { medication, financing } \\
\text { (credit facility) and } \\
\text { marketing assistance. }\end{array}$ \\
\hline
\end{tabular}

Source: Compiled by authors based onextensive literature review \&expert'sinterview.

Chart no - 1B (Research schema)

\begin{tabular}{|l|l|l|l|}
\hline $\begin{array}{l}\text { Value } \\
\text { activities } \\
\text { (Parameter) }\end{array}$ & $\begin{array}{l}\text { Generic } \\
\text { categories } \\
\text { (Complex } \\
\text { Variable) }\end{array}$ & $\begin{array}{l}\text { Definition of Porter's } \\
\text { activities on poultry hatchery } \\
\text { (Definition of complex } \\
\text { variables) }\end{array}$ & $\begin{array}{l}\text { Major activities in } \\
\text { relation to poultry } \\
\text { hatchery (Simple } \\
\text { Variables) }\end{array}$ \\
\hline $\begin{array}{l}\text { Support } \\
\text { activities }\end{array}$ & Procurement & $\begin{array}{l}\text { The most distinctive support } \\
\text { activities of poultry hatchery } \\
\text { which include sourcing of best } \\
\text { quality hatchery related } \\
\text { necessary materials, negotiating } \\
\text { at the best price and ensuring } \\
\text { availability as per the demands } \\
\text { of the business operations on } \\
\text { time }\end{array}$ & $\begin{array}{l}\text { Purchase of land, building } \\
\text { material, plant, machine, } \\
\text { lab equipment, and office } \\
\text { equipment, DOC of } \\
\text { different generations and } \\
\text { varieties, poultry feed } \\
\text { materials and other } \\
\text { accessories. }\end{array}$ \\
\hline
\end{tabular}




\begin{tabular}{|c|c|c|}
\hline $\begin{array}{l}\text { Technology } \\
\text { Development }\end{array}$ & $\begin{array}{l}\text { Technology development of } \\
\text { poultry hatchery may be } \\
\text { defined as the use of time tested } \\
\text { global poultry hatchery } \\
\text { technology with appropriate } \\
\text { technical know-how to } \\
\text { maximize quality and } \\
\text { productivity. }\end{array}$ & $\begin{array}{l}\text { Introduces } \\
\text { environmentally controlled } \\
\text { shade, automatic setter, } \\
\text { and hatcher for DOC } \\
\text { production and appropriate } \\
\text { equipment for bio-security } \\
\text { and waste management. } \\
\text { Best quality auto feed } \\
\text { plant for poultry feed } \\
\text { production. Established } \\
\text { well-equipped lab with } \\
\text { research development and } \\
\text { innovation team }\end{array}$ \\
\hline $\begin{array}{l}\text { Human } \\
\text { Resource } \\
\text { Management }\end{array}$ & $\begin{array}{l}\text { Integrated activities related to } \\
\text { enhance capacity building } \\
\text { resulting high productivity of } \\
\text { human resources at every tier of } \\
\text { poultry hatchery management. }\end{array}$ & $\begin{array}{l}\text { Forecasting, budgeting, } \\
\text { planning, recruiting, } \\
\text { selecting, compensation } \\
\text { management, training, } \\
\text { motivating and } \\
\text { performance evaluation of } \\
\text { poultry hatchery's human } \\
\text { resources. }\end{array}$ \\
\hline $\begin{array}{l}\text { Firm } \\
\text { Infrastructure }\end{array}$ & $\begin{array}{l}\text { General managerial and } \\
\text { structural activities to support } \\
\text { and accelerate the integration of } \\
\text { poultry hatchery value chain. }\end{array}$ & $\begin{array}{l}\text { Setting vision and mission } \\
\text { of individual poultry } \\
\text { hatchery, financing, } \\
\text { managing utilities (e.g. } \\
\text { power, water, gas etc.) and } \\
\text { communications, legal and } \\
\text { regulatory affairs related } \\
\text { to community amenity and } \\
\text { health. }\end{array}$ \\
\hline
\end{tabular}

Source: Source: Compiled by authors based on extensive literature review \& expert's interview.

According to the Industrial policy of Bangladesh 2005, definition of SME has been in terms of fixed assets and no. of employees of three major sectors: service, manufacturing and trading but the present definition which was recommended by Better Business Forum and accepted as a uniform one by Ministry of Industry and Bangladesh Bank included Cottage and micro industry as SME in Bangladesh. Bangladesh Bank has revised the SME definition through its ACSPD Circular No.08, dated 26th May, 2008 and then through its SMESPD Circular No.01, dated 19th June, 2011. Accordingly the medium manufacturing concern are defined as the enterprises which have total fixed assets of BDT 1000-3000lac and no. of employee is 100-250 and small manufacturing concerns which have total fixed assets 50-1000lac and total number of employee is in between 25 to $99 .[8,9 \& 10]$

However on the basis of feedback from focus group discussion and subsequent in-depth interviews with the hatcheries professionals, following working definition has been proposed by these authors for analyzing poultry hatcheryin Bangladesh(Shamsuzzaman,M \&Jahan, M., 2017) 
International Journal of Managing Value and Supply Chains (IJMVSC) Vol. 8, No. 3/4, December 2017

Proposed SME s Classification of Poultry Hatcheries in Bangladesh

\begin{tabular}{|l|l|l|l|l|}
\hline Class & $\begin{array}{l}\text { DOC } \\
\text { Production Capacity } \\
\text { (Per week) }\end{array}$ & $\begin{array}{l}\text { DOC } \\
\text { Regular } \\
\text { Production (Per } \\
\text { week) }\end{array}$ & Capital & Employment \\
\hline Small & More than 50,000pcs & Below 50,000pcs & Below 50 crore & Below 100 \\
\hline Medium & $2,00,000-3,00,000$ pcs & $\begin{array}{l}50,000 \text { to } \\
2,00,000 p c s\end{array}$ & $50-100$ crore & $100-250$ \\
\hline Large & More than 3,00,000pcs & $\begin{array}{l}\text { More than } \\
2,00,000 p c s\end{array}$ & $\begin{array}{l}\text { More than } 100 \\
\text { crore }\end{array}$ & More than 250 \\
\hline
\end{tabular}

Source: Shamsuzzaman,M \&Jahan, M. (2017).[11]

\section{RESEARCH METHODOLOGY}

A series of rigorous literature review has been conducted on basic model of Porter's Value Chain, various research journals of Porter's Value Chain relating to poultry business, reverse poultry value chain and several factors and variables that influence integrated poultry value chain. The researchers also concentrated highly on all operational practices of poultry hatcheries through applications of both theoretical and practical knowledge which has facilitated the use of appropriate methodology to conduct the proposed research successfully. The entire research is based on sufficient primary and secondary data.

Sources of secondary data include internationally published research papers of relevant internationals journals, keynote papers of various seminars, statistical year books, reports of international and national NGO's related to poultry hatcheries and its value chain management and annual reports of public limited company.

On the basis of primary and support activities of Porter's Value Chain, an elaborate chart (research schema) has been developed by the researchers, which has also been reconfirmed by conducting two separate focused group discussions, with each group consisting of eight participants from different functional departments of hatchery business, of same or different organizations. Primary data has been collected through in-depth interview (based on the charts) of entrepreneurs and senior management professionals of six large hatcheries and $14 \mathrm{SME}$ hatcheries, together covering more than $60 \%$ of the hatchery businesses of Bangladesh. In-depth interviews of some responsible professionals from the department of Livestock Service, Bangladesh Livestock Research Institute (BLRI) and key professionals of poultry association havebeen conducted.

Some of the hatcheries including large, medium, and small were visited by the researcher to know about existing value chain activities. Comprehensive interviews along with focus group discussions were conducted with different tiers of hatchery professionals. These were the most important tools used for primary data collection. The judgmental sampling method was used to collect data, since respondents were selected on the basis of their knowledge on the value chain integration of poultry hatcheries. Researchers also spent time with two renowned poultry consultants for collecting latest information of poultry hatcheries, its value chain and how to create sustainable competitive advantages. Consultations with two responsible officials of environmental department regarding bio-security, safety and waste management of poultry hatcheries, were further carried out by them. 
International Journal of Managing Value and Supply Chains (IJMVSC) Vol. 8, No. 3/4, December 2017

\section{RESEARCH FINDINGS}

\subsection{Inbound Logistics:}

In the poultry industry of Bangladesh, there are seven larger hatcheries which import GP DOC, and produce PS DOC for their own use, as well as sell those to the small and medium hatcheries across the country. Most of the SME hatcheries purchase PS DOC from them, except a few medium size hatcheries who import PS DOC from abroad for ensuring better quality. Almost all large hatcheries produce poultry feed in commercial manner for use in their own hatcheries and also to sell to broiler and layer farms. However, the poultry feed plants owned by the SME players are only used for their internal consumption except a few medium size hatcheries who make external sales.

Considering the importance of this issue, one of the renowned industry consultant opined that Government is consciously avoiding a fundamental support at the elementary phase of the business.

Across the hatchery size, all of them do air shipment those who import GP and PS DOCs but most of them are not conscious about the carrier's bio-security and safety measures.

While importing GP and PS DOCs, most of the players (across size), follow traditional methods such as manually picking and loading by hand, onto the vehicles. Warehousing steps is missing at the airport, hence, there is no allocated or appropriate space for warehousing to test the DOC, as per the quarantine policy of the country. In this regard government is very flexible, due to lack of equipment, lab facilities and skilled professionals which are very important for the poultry industry, considering bio-security and safety issue.

Research findings regarding transportation of GP and PS DOC is that, except two farms, the GP breeder farms use traditional hired $\mathrm{AC}$ bus as the carrier of DOC from airport to their farms. Medium farms that import PS DOC, also carry DOC by traditional AC vehicle from airport to their farms.

Managing directors of one of the big players has remarked,we have our own AC bus for carrying DOC which is very modern and which ensures maximum safety and bio-security of DOCs.

However, these traditional AC buses, used by the industries are not at par with the modern global standard of DOC truck such as VEIT- Day old chick truck. As a result, there is a big doubt whether their AC bus is good enough to prevent DOCs from pathogenic attacks and environmental factors during transportation, since GP DOC is highly susceptible.

The larger farms carry their PS DOC from GP farms to their PS farms through traditional AC bus; however, while delivering to local customers, they simply resort to traditional open vanswith well-ventilated steel racks which barely cover bio-security and safety precautions, causing risks of viral, bacterial and other pathogenic infections. Far worse is when, in most of the cases, SME players carry PS DOC from the supplier hatcheries, by traditional vans.Very noticeable observation is that some small players use even manual van to carry their PS DOC.Therefore, and it is evident that most of the SME players start their business operations with pathogenic risk especially viral infection.

In case of poultry medicine transportation, some of the medium sized poultry hatcheries, who have the poultry medicine production facility under the same umbrella, are using proper transportation systems for transporting the medicine from their plants to the hatcheries. They are also preserving the medicine in the hatchery premises, maintaining proper standard. For the large and few medium hatcheries, the medicine is usually delivered to the hatchery premises via the manufacturers' vans, which are well maintained for the particular medicine. These large players 
also try to preserve the medicines as per minimum standard. The medicine manufacturers usually do not deliver to the small and some medium hatcheries, indirectly forcing them to buy medicine from agents due to small purchase quantity and inconvenient geographical location. In most of the cases, the agents do not have the right sensitivity for preserving medicine in a proper manner. This usually involves high risk and is not the safest option as it affects DOC's productivity, and mortality rate.

In case of poultry feed transportation, all players use more or less similar means. Where most of the large players have their own transportation network, others use hired van. As a result, the large players are at an advantage in terms of cost efficiency as well as better distribution.

Regarding inventory management, research finding is, all large farms (6 respondents), and some medium size farms (3 out of 7 respondents) which are the SBUs of conglomerate, use ERP software for their inventory management. The rest of the medium size farms (4 out of 7 respondents) and some small players (4 out of 7 respondents) use traditional inventory software. Three out of seven small players use traditional Microsoft programs such as excel and word files.

\subsection{Operations:}

While interviewing the entrepreneurs or senior management personnel of large enterprises, the research effortexplored, the four major points regarding their operational management process: 1) Placement of skilled human resources at every tier of operations, 2) Use of modern technology such as controlled shades \& auto-setters and hatchers etc. 3) Practice of the best methods approved by international body and 4) improve processes for alleviating effectiveness and efficiently of productivity. However, in the global context, they are much behind the international standards of operations, since each and every day, new technology and methods are being developed by the global giant players through their research, development and innovation divisions. That is why, our large players are not yet ready to explore their markets crossing the local boundary.

Except few medium players, most of the SME players (10 out of 14 respondents) follow traditional operational management processes which reduces both their productivity and quality while increasing production cost as well. It is one of the prime barriers for the SMEs in creating competitive advantage to compete large players.

Larger hatcheries usually maintain a longer value chain compared to the SME hatcheries, since they have longer backward linkage. This gives them a price advantage while using the PS DOC from their own hatchery and attractive profit margin earn by selling their PS DOC to SME players as well. It is the most noticeable sustainable competitive advantage for the large player.

Some medium hatcheries ( 3 out of 7 respondents) import the PS DOCs instead of buying them from local players since they believe that the imported PS DOC are of an improved quality and yield quality Commercial DOC compared to the local PS DOC. Questioned raised in the research finding whether the quality PS DOC producer are at the international standard or not. Tried to dig out it but it's require close monitoring, R\&D support and huge time consuming to do the proper comparative study. It's a serious issue to distinguish, since except few medium size hatcheries all SME players purchase their PS DOC from 7 large players. In our study it has been found that twelve out of fifteen of the SME players purchase PS DOC from the 7 large players of the market, who in turn become their competitors since both parties produce Commercial DOC from the PS DOC.

It has been commented by many SME respondents, at the grading stage GP hatcheries keep the superior PS DOC for their own production and sell the remaining to the SME players. Though GP hatcheries always try to produce homogeneous PS DOC in respect of quality. As a result, this 
puts the SME players at a disadvantage since their commercial DOCs might be of lower quality compared to the larger players.

For feed production, large hatcheries use advanced technology such as Auto Feed Mills, since they use the feed in their own firms, as well as sell it to the small hatcheries, commercial broiler and layer producers. By which they are making profit which help them to do integrated marketing communication and manage their respective agents to force them selling commercial DOC. However, major SME players who do not sell the feed to other commercial broiler and layer producers use traditional grinding and mixing machines to produce poultry feed due to insufficient financial back up and volume of production, which creates confusion of standard quality, can hamper PS DOC quality.

Three out of seven medium sized players have a poultry medicine production unit that are at an advantage in terms of cost saving and support services. In some cases, few large hatcheries claim that they import or purchase (poultry medicine) from global players for ensuring better quality. It's a controversy between large players and medium size hatcheries with local medicine production facilities.

Poultry industry faces huge crisis of skilled professionals for running and maintaining the modern equipment. Only the large hatcheries get support from their suppliers or collaborators to train their people properly, given that they can make agreements on full package technical support. On the contrary, the cost of technical support charge seems so high that it is not practically affordable by the small and medium hatcheries. That is why, they try to avoid integrated training program for developing their team players. Another constraint is the lack of availability of local experts who can ensure proper training on modern equipment and technology. On the basis of research findings, it can be concluded that large players are in much advanced stage than SME players, in terms of implementation of new technology.

Considering economies of scale, large players are at an advantage in terms of product quality, productivity and cost saving. Considering quality assurance and trust factors SME players are not in better situationcompared to large players to the customer base which is one of the key barrier to grow.

The management of hatchery industry as a whole is well acquainted with the term - Bio-security and safety and shown their high passion to implement in the hatcheries. Respondents of all large and medium farms are notified that bio-security and safety practices are being strictly followed by them. It's a very interesting research finding that different farms define and practice integrated bio-security and safety methods, differently, which, in most of the cases, do not align with the global standard. Most of the players (14 out of 20) implement bio-security only on entry and exit point, which although important, does not holistically solve the problems. For examples, vaccination equipment can also carry pathogen to the farms, which requires proper bio-security measures before entrance into the farms. In many cases, these small pathogen carriers are not noticed or treated properly. Five of seven small hatcheries agreed that they need to be more careful on these issues to improve the complete poultry hatchery operation.

The entire industry fails to establish a set of standard for managing all waste of hatcheries effectively and efficiently. As a result, different players practice waste management in their own standard of operation.

Researchers, on the basis of their research findings, conclude that large and few medium players are focusing to manage major waste effectively. About $80 \%, 50 \%$ and $20 \%$ of the large, medium and small players respectivelymore conscious about waste management for the community, amenity and health. 


\subsection{Outbound Logistics:}

Handling of DOC after hatching is one of the most sensitive but small phase of the total value chain. Most of the global players follow modern technology for handling, grading, packing, printing, transporting and loading into the vans and unloading to the supplier's point. In our country, starting from the large players to the small players, none practice this integrated method. Even though, most of the large and few medium players claim that they are following the modern technology due to knowledge gap with the latest global technology or using old machineries which was modern when it was introduced. In case of small hatcheries, realizing the sensitivity of this stage is still a big challenge.

Most of the large hatcheries are using ERP or traditional inventory management software in to order take orders, process orders, and then schedule their distribution vehicles. Some medium players which are the SBU of conglomerates also follow the same system. Few medium and small players, having the IT knowledge, are also practicing the same, whereas, for other SME players, it is an important area of improvement.

DOC packing is sensitive as well as important considering bio-security and safety of the DOC. All large players and most of the SME players are using semi-automatic packaging system where as global players' use fully automatic packaging. As a result, human contact can be avoided.

In case of transportation, most of the large and medium players use traditional vans which are inappropriate for carrying the DOC from the hatchery to the farmers or agents. Few small players use even ordinary vans for carrying DOC to the agents, which is a very unsafe and improper way to carry the DOC. Nobody is taking care of this part. As a result, the farmers are affected.

In poultry industry, intermediaries, especially dealers or distributors play a vital role for secondary distribution of commercial DOC, as contact farming has not yet been established professionally in Bangladesh. Due to a lack of cautiousnessof the sensitivity of DOC handling and transportation, they use vehicle on the basis of availability and handle the DOCs with least care, which increases pathogenic susceptibility.

\subsection{Marketing and Sales:}

The prime objective of marketing is to create sustainable competitive advantage, which requires develop and manage longer but creative vertical value chain starting from rearing and breeding to produce processed meat. Global giant players, maintain longer vertical value chain with continuous value creation. Few large players like Kazi Farms, CP and AG poultry try to make their value chains longer, as well as, launch some value added products such as green meat and halal meat. Some larger players are also has some visionary plan to produce organic meat to feed the global market. In this aspect, SME players are far behind.

One of the other important marketing tools is pricing strategy for poultry hatcheries. Again, this industry is very critical due to the high impact of seasonal variation across the year. It is difficult for players to forecast the seasonal influence of DOC selling, because different year appear differently in case of seasonal variation. Peak, semi-peak, non-peak season play a vital role for determining the pricing strategy because the pricing gap between the peak and non-peak season is less than half. During the non-peak season, in most of the cases, price is less than the cost price of DOC, which is applicable for maximum mediums and all small players. But large players are able to manage the cost price even during the dull or non-peak season. In case of some small players, one non-peak season can play a shocking role to block their working capital for selling DOC at a much lower price than production cost. 
As per research finding, large players cost of goods sold is 5 to 10 percent less than that of SME players due to longer value chain and higher bargaining power. This is the vital sustainable competitive advantage over SME players. On the other hand, large players always charge premium prices than SME players due to their brand image and better services. Comparatively, the SME players charge 2 to 4 taka less which is 5 to 10 percent less than what the large players are charging. In both the cases, SMEs have to suffer since they have a higher cost and are forced to charge a lower price. As a result, they are not as profitable as they as they desired to be, and this is one of the main reasons why the entry and exit of SMEs are very high in the market. This is the key constraint for inclusive growth of the total poultry industry of Bangladesh.

Large players have strong secondary distribution network (distribute to farmers), since they have greater opportunity to select the dealers or distributors who have strong financial backup, solid business bonding, large broiler and layer farms, well organized transportation facility, better technical knowledge and skills. They also have integrated support capacity to supply DOC feeds and medicine etc. together on credit and they take responsibility to sell their end product like eggs, live birds etc. through which they recover their credit outstanding. As a result, large dealers and distributors are also highly interested to take distributorship of large hatcheries because they get poultry feed on credit and can sell DOC at a higher profit easily due to higher market demand and brand image except few medium size hatcheries, most of the SME players' secondary distribution network is weaker considering all parameters which is one of their biggest weaknesses.

Some of the small regional players try to distribute their DOC directly to the commercial broiler and layer farms but, they do not have sufficient fund to either provide credit facilities on DOC or to supply feed and medicine as per the farm's requirement. They also fail to take the responsibility of selling farmers' products such as live birds and eggs. As a result, bonding between small hatcheries and the commercial farms is not as strong as that between large and medium farms.

In very few cases, some local small hatcheries are at an advantage because of the convenience of location. As a result, they can maintain stronger bonding with the regional commercial broiler and layer farms across size. Generally, most of the large hatcheries have poultry, fish and animal feed businesses. For feed, many of them advertise in the electronic media which puts them at an advantage in selling commercial DOCs. SMEs, however, often lack such opportunities.

Large and aggressive medium players also advertise through electronics, print media, professional journals, souvenirs, leaflets, booklets etc. where small players are absent. The large and medium players also draw attention to potential buyers through their participation in local fairs and also plan on extending their presence in the foreign exhibitions.

Large players launch distributor motivation schemes such as foreign trip, attractive gifts and special discounts for achieving higher growth as well as for blocking access of their competitors. For small players, it is often not feasible to engage in such activities due to small sales volume.

\subsection{Service:}

All large players, and most of the medium players have techno commercial teams for rendering technical support to their potential customers such as land and location, shade, DOC, feed and medicine selection, its effective utilization, training for using best practices for broiler and layer farmers, business model preparation with feasibility study analysis. For which they can acquire mostpotential new customers. But most of the SMEs (9/14) players are in backward situation in terms of new customer acquisition due to lack of necessary support service. 
Large farms are in a much better position in respect of customer relationship management due to their longer value chain and individual departments for customer service. This helps to retain customers as well as win back lost customers. Most of the SME players don't have individual customer care departments for handling customer complains, counselling and technical advice as and when necessary. There are some small players who do not even have trained and skilled sales team for handling customer complaints. As a result, customer retention and customer win back is a very big challenge for them.

Large and few medium players give credit to their distributors on poultry feed which helps them selling DOC on cash and pushing it in the semi-peak and non-peak season. But most of the SME do not have commercial poultry feed production facilities, facing more challenge to sell their DOC on cash to the distributor.

Government service providing department also more cohesive with the large and progressive medium hatcheries, so they have easy access to furnish any sort of government requirement and also get quick response for any kind of help require for the hatcheries. But small players have very limited access to the government offices which is more important for them than large and aggressive medium players.

\subsection{Procurement:}

It goes without saying that procurement plays a vital role in value chain integration for any industry. Particularly, it is most sensitive to the poultry industry which deals with livestock and agricultural poultry feed ingredients. The price index in the global market for agricultural products such as poultry feed ingredients, is extremely volatile. It's requires professional team players having the appropriate connectivity with the global market and updated information. This kind of facility is only availed by the large and few medium players. Due to having procurement professional as well as high capacity of bulk purchase (5 large players including Kazi\& CP occupying more than $60 \%$ market share), the large players enjoy higher price benefit from the global or international suppliers in comparison to the SMEs in case of import. As a result, SMEs mostly buy poultry feed ingredients locally resulting significant gap in feed pricing.

Since large players own a longer value chain, which starts from Grand Parent DOC, they have higher access and greater exposure to the Global giant hatcheries. As a result, they are also getting more co-operation and collaborative support from them which helps to gain a strong technical foothold. The SMEs are fully deprived of such advantages. The large players can produce Parent DOC for their own use to, in turn, produce commercial DOCs, also selling Parent DOC to the SME hatcheries. The cost of production, therefore, is naturally lower, which is one of their most important sustainable competitive advantage over the SME players.

Due to higher economies of scale, strong financial backup and rich knowledge on modern technology, large players are always in favor of adapting newer technology to improve their quality and productivity to add more value in their product and services. Hence, large players are always in the good books of the largest global equipment manufacturers. Every new equipment that enters the market, thus, is first made available to them instead of the SMEs who neither have the affordability or the benefit of positive relationship with the suppliers. Even if SMEs do consider adapting to better technology in a small scale, they are still deprived of the price advantage from the suppliers.

As per Porter's Five Forces model, it can be concluded that SME players face severe competitive tension from large hatcheries due to higher bargaining power from both the supplier and buyers' end. 


\subsection{Technology Development:}

Most of the SMEs, especially small players (10 out of 14 respondents) agreed that they are not at par the large players, and far behind the global players in terms of technological advancement. Many of the small enterprises do not have updated understanding about modern technological advancements in terms of biosecurity and safety issues, vaccination, medication, automation, and modern hatchery equipment.

Large firms stand firmly on the fact that, the technology they are currently using is the most advanced, and the most modern one, but in reality, they are till behind comparing with the global leaders. This is mainly due to the rapid changes of the technological innovations in the global market. Even that is true, they are still ahead of most of the SMEs in terms of technological advancements. Most of the large players buy equipment mostly from the prominent global suppliers. This enables them to remain updated with the technical know-how, an opportunity that the SMEs cannot avail.

Small and medium firms are still abiding by the traditional and conventional forms of technology. This is because, they believe that improving their current technology will only increase the yield by a fraction, but will increase the overall costs drastically. They feel that they are more equipped with their existing technological ability.

There is an information gap in the poultry industry especially for the SMEs, as they have not been properly educated about the benefits of modern technology. On the contrary, SMEs have limited understanding on how to commercialize technology and harvest its benefits due to lack of promotional knowledge as well as how to communicate the features and benefit of acquiring newer technology.

International seminars, symposiums and conferences are often attended by large players that adds to their advantage in keeping them updated with the knowledge of the latest technology that can increase the efficiency of their business operations. This culture is rarely cultivated among the SMEs.

Above all, one of the core barriers for the SMEs' to introduce modern technology is lack of capital in terms of accessibility, availability and affordability. Especially the small players have a very limited access to any source of funding. Furthermore, whatever funding they do manage, is usually through a very high rate of interest compared to others, which affects their affordability.

\subsection{Human resource management:}

Somelarge and few medium players properly follow the HR budgeting, planning, recruitment and selection processes but some medium and most of the small players not only have proper HR planning process but also prioritize recruitment of their relatives as well as acquaintances at the expense of desired quality which is a big barrier in their capacity building process.

The industry culture pays less focus on conducting training for employees even though the industry requires professional knowledge and skills. Large and medium players and very few small players organize training program or allow their employees to attend training programs in irregular manner. On the other hand, sufficient skilled trainers are not available to train different layers of employees of the hatchery industry. The greatest sufferers of such practices are mostly the SMEs as most of the large players have global collaborators to provide minimal training to their employees.

The compensation package of the industry as a whole is comparatively lower than the other industry averages. For this reason, many hatchery professionals opt to switch to other industries. As a result, large players have now started to improve their compensation packages. It is 
noticeable that there are some medium players who are part of the conglomerate, pay better compensation packages compared to others. Small firms aren't ensuring the compensation package as per standard of the industry. As a result, their employee turnover is higher resulting lower productivity.

Some large and few medium players are initiating employee motivation programs which boosts their productivity, increasing the overall efficiency of the operations. The SMEs are quite indifferent regarding this aspect.

\subsection{Infrastructure:}

Except very few large and medium players, most do not have a precise vision, which is one of the biggest shortcomings of the entire industry. Most of the players are mission driven but not in a structured manner.

In terms of financing, large and medium players are in a better situation than the small players for various reasons related to financial policies of the government and attitude of the financial organizations.

Considering the present infrastructural scenario, especially utilities such as gas, electricity connectivity etc., only the large players are getting priority over the SMEs due to higher accessibility to the concerned government officials.

In term of Total Quality Management (TQM) practice, except few corporate houses, rest of them are very reluctant to practice TQM which is the big challenge for the large players to cross boundaries in order to compete with the global players.

\section{RECOMMENDATIONS AND CONCLUSION:}

The research has found that larger hatcheriesenjoy significant competitive advantage over their SME counterparts due to extensive value chain presence, use of modern technologies, methods and processes, stronger brand image, proper marketing activities, effective customer services, better economies of scale and scope, continuous technological development, proper people management and stronger infrastructural support.

However, the industry offers significant scope of improvement. The following are some of the priority recommendations that this research offers:

$>$ Government should take all necessary steps to establish and implement international animal quarantine procedure before releasing any DOC from the airport, which will protect our industry from foreign pathogenic transmission into the country.

$>$ Industry as a whole needs to improve the transportation system of GP and PS DOC as per the international standard. This requires a national DOC and poultry medicine transportation as well as preservation policy for poultry hatcheries. Government should extend financial support to execute the policy, especially for the SME players.

$>$ The Government,individually or in collaboration with the Hatchery Association, should take proper initiative to organize advance training program, seminar, symposium, and workshop on production re-engineering, adopting modern technology and practices of the best methods which are very much required for the SMEs.

$>$ Bangladesh Livestock Research Institute(BLRI) should take initiative to produce PS DOC at international standard with a consistent pricing strategy, especially for the SME hatcheries, which will give the price indication of PS DOC producer across the year, reduce theproduction cost of commercial DOC and improve the quality. 
$>$ The Government, in collaboration with the Hatchery Association, should prepare a timetested national policy on bio-security, safety and waste management and ensure its proper implementation. In this regard, the Government should ensure necessary financial backup and technological support to the industry.

$>$ The poultry hatchery industry should rethink about a new business models considering contact farmingwhich is the basic infrastructural requirement to improve the industry holistically, since it is the common practice in the most modern countries.

$>$ The Government should redefine the SME Poultry Hatcheries to enable them to enjoy the facilities offered by the Government to SMEs of other industries.

$>$ Government service departments should work more cohesively with SMEs rather than the large poultry hatcheries.

Given that the knowledge gap is minimized, the necessary technology attained and government participation ensured, the poultry industry of Bangladesh has a huge potential of paving its way to meet the local demand and enter into the global market.

\section{ACKNOWLEDGEMENTS:}

We are highly grateful to Tariquzzaman, Director, Strategy Planning \& Brand Marketing, Abu LuthfeFazle Rahim Khan, Managing Director, AftabBohumukhi Farms Ltd.; ManzoorElahi, Chief Coordinator, Paragon Pultry Ltd.; Md. SamiulAlim, GM (Sales \& Marketing), Nourish Poultry \& Hatchery Ltd.; Kbd Md. Rasheduzaman, Dr. Taposh Kumar Ghosh, One Pharma Ltd.; Dr. Md. Shakil Hossain, Technical Manager, Innova Animal Health; Md. Rakibur Rahman (Tutul), Managing Director, Kbd;ShafiulAlam (Uzzal), DGM (Sales) , Nahar Agro Group; Ekhlasul Haque, Managing Director, Chicks \& feeds; Md. Lutfor Rahman, CEO, AG Agro Industries Ltd.; KhondokarHasnat Karim, Managing Director, Community Farms Ltd.; Iqbal Mahmud, Joint Secretary, Ministry of Agriculture; Mohamed Aftab Uddin, Deputy General Manager, Kazi Food Industries Ltd.; Tarokeswa Das, Sr. Manager, Production, Kazi Farms Group; Mr. Sayed Sultan Ahmed, GM-Sales; Dr. Abu Sadat Md. Sayem, Sales Manager, Fish Feed Sales; Mr. Mohammad Shaheen Shah, Business Director; Mr. Mohammad Abdullah, General Manager, Marketing Operation, ACI Animal Health, ACI Limited; Mr. Jahirul Islam Khan Hero, Executive, Breeder's Association of Bangladesh; Mr. A K M Salah Uddin Sarkar, Managing Director, Advance Agrotech (BAD) Ltd.; Mr. Md. SirajulHoque, General Manager, Animal Health Division, Renata Limited \& General Secretary, World Poultry Science Association, Bangladesh Branch; Krishibid Mr. Md. Shohidul Islam, Upozila Livestock Officer, Poultry \& Dairy Consultant; Dr. A.B.M. Khaleduzzaman, Upozila Livestock Officer; Mr. Bibek Chandra Roy, Upazila Livestock Officer, Mr. Nokib Ulla Siddiquee, Asst. Director (Farm), Department of Livestock Services, Krishikhamarsarak, Farmgate; Mr. Saidur Rahman Babu, Managing Director, S.B. Hatcheries Ltd. \& General Secretary, Breeder Association of Bangladesh; Mr. GolamShajleeAdeeb Chowdhury, Director; Mr. BiplobSamadder, Account Executive; Mr. Md. Nazrul Islam, Marketing Executive, Shamoli Poultry Ltd.; Krishibid Mr. Md. Jahangir Alam, General Manager, Abir Poultry Hatchery \& Process Limited; Mr. Md. Mahabubur Rahman, Managing Director, Peoples Feed Ltd., Peoples Poultry \& Hatchery Ltd., Mr. Md. Ashfaqul Islam, General Manager; Mr. ShaheedIsrail Khan, Chicks \& Feed; Dr. Debashis Paul, Head of Sales \& Marketing (Cattle Feed), ACI Godrej Agrovet Private Ltd.; Md. Afzal Hossain Divisional Manager (Sales). We would like to express out heartiest gratitude to above all for their cooperation, co-ordination and providing necessary information to complete the research work. 
International Journal of Managing Value and Supply Chains (IJMVSC) Vol. 8, No. 3/4, December 2017

\section{REFERENCES:}

[1]. Bangladesh Economic Review 2014, Economic Adviser's Wing, Finance Division, Ministry of Finance.

[2]. http://www.thefinancialexpress-bd.com/2016/07/28/39843/Bangladesh (Accessed on 10/01/17)

[3]. OECD-FAO Agricultural Outlook, 2016

[4]. Kaplinsky, R. and Morris, M. (2001) A Handbook for Value Chain Research, Prepared for the International Development Research Centre (IDRC), pp.4-6, 9-14, 25-32.

[5]. WBCSD (2011) Collaboration, innovation, transformation: Ideas and inspiration to accelerate sustainable growth A value chain approach, p.3 \& 5 (emphasis added) (Accessed 19/11/16).

[6]. Porter, E. M. (1985), Competitive Advantage; Creating and Sustaining Superior Performance. pp 3361. First Free Press Export Edition 2004, New York.

[7]. Proctor, F. and Lucchesiv, V. (2012); Mapping Study on Value Chain Initiatives in ACP Region, pp. 1-8, 10-11, 17-23, 55-62.

[8]. Ahmed, K and Chowdhury, A.T (2009), Performance Evaluation of SMEs of Bangladesh. International Journal of Business and Management, Vol.4,No.7

[9]. Small and Medium Enterprise (SME) Credit Policies \&Programmes, SME \& Special Programmes Department Bangladesh Bank Head Office, Dhaka

[10]. Performance Evaluation of SMEs of Bangladesh, International Journal of Business and Management Vol.4, No 7, July 2009.

[11]. Shamsuzzaman,M and Jahan, $\mathbf{M}(2017)$, SMe Development Challenges and Opportunities in Bangladesh: A Case Study on Poultry Hatcheries by Triple Triangle Framework(TTF), international Journal of Sciences: Basic and Applied Research.pp.173-192.

[12]. Sustainability, UNEP and UNGC (2008) Unchaining Value: Innovative approaches to sustainable supply, p.2 (emphasis added) (Accessed 19/11/16).

[13]. GHG Protocol (2011) Corporate Value Chain (Scope 3) Accounting and Reporting Standard Supplement to the GHG Protocol Corporate Accounting and Reporting Standard, World Resources Institute (WRI) and WBCSD, p.141 (emphasis added) (Accessed 19/11/16).

[14]. A journal published by the department of Agriculture, Forestry and Fisheries, Republic of South Africa (2014); "A Profile of South African Broiler Market Value Chain".

[15]. Ayele, G. and Rich, M. K. (October 2010); Poultry Value Chains and HPAI in Ethiopia, Africa / Indonesia Team Working Paper 25.

[16]. Shamsudduha, M. (2011); Applying Reverse Supply Chain in the Poultry Industry.

[17]. Prahinski, C. and Kocabasoglu, C (2015); Empirical research opportunities in reverse supply chains. Omega: International Journal of Management Science 34 (6): 519-532.

[18]. Masole, C. Mphothwe, K.G. and Moreki, C.J. (2015); "Value Chain Analysis of Bostswana Poultry Industry: The case of Gaborone, Kgatleng, Kweneng and South East Districts". Journal of World Poultry Research 5(3): 64-72.

[19]. http://www.ifm.eng.cam.ac.uk/research/dstools/value-chain-/(Accessed date 16/01/17)

[20]. Kocabasoglu, C., Prahinski, C., \&Klassen, R. D. (2007). Linking forward and reverse supply chain investments: The role of business uncertainty. Journal of Operations Management, 25(6), 11411160.

[21]. Shamsuddoha,M. Quaddus,M and Klass,D.(200) Reducing Environmental Hazards through Reverse Supply Chain Model. 


\section{AUTHORS:}

M. Shamsuzzamn has more than 26 year hardcore experience in Sales and Marketing including more than 13 year as Business Head in a number of local and multinational companies. Currently he is working as Director Business Operations to look after AKzoNobel Paints brands in Bangladesh.He holds a BSc in agricultural science and MBA in marketing. He has been teaching marketing for the last 6 years as a visiting faculty at the status of Associate Professor in Daffodil International University, Bangladesh. Now he is a research fellow of Doctor of Business

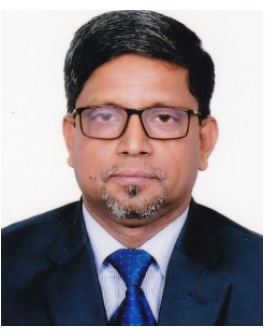
Administration (DBA) in the Institute of Business Administration, University of Dhaka, Bangladesh. His area of research is "How to create sustainable competitive advantage in business".

Sheikh MorshedJahan is a business school professor with 24 years of experience in executive education, research and consulting. His areas of expertise include inclusive market development, business strategy and growth acceleration, global value chains, business ecosystem, sustainable business model, SME promotion, rural and BoP markets, emerging economy agribusiness and institutional arrangement. As a consultant, he served in projects funded by UNDP, UNESCAP, USAID, World Bank, SDC, UKaid, DFID, Sida, CIDA, Danida,

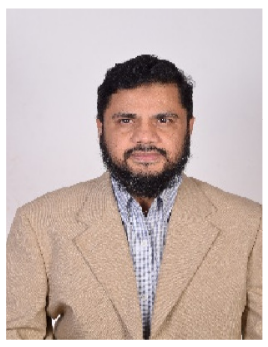
ASEAN Economic Research Institute, ILO, Save the Children, Samsung, KNI, G4S, Radio Today, etc. He served as a member of UN-ESCAP Advisory Panel on SME Development in Asia and the Pacific. He executed assignments in Bangladesh, Bhutan, Kazakhstan, Laos, Mongolia, Nepal, Philippines, Cambodia and the USA. Currently based at IBA-University of Dhaka, he was a World Bank scholar at Duke University's Program in International Development Policy and a Commonwealth Fellow at IIM-Ahmedabad. 